\title{
Impact of Accelerated Stresses on Power Transformer Insulation
}

\author{
Jashandeep Singh ${ }^{1}$, Yog Raj Sood ${ }^{2}$, Piush Verma1 \\ ${ }^{1}$ Rayat-Bahra Group of Institution, Patiala, Punjab, India \\ ${ }^{2}$ NIT, Puducherry, India \\ Email: jashanjb@gmail.com
}

How to cite this paper: Singh, J., Sood, Y.R. and Verma, P. (2017) Impact of Accelerated Stresses on Power Transformer Insulation. Energy and Power Engineering, 9, 217-231

https://doi.org/10.4236/epe.2017.94015

Received: July 18, 2017

Accepted: April 17, 2017

Published: April 20, 2017

Copyright $\odot 2017$ by authors and Scientific Research Publishing Inc. This work is licensed under the Creative Commons Attribution International License (CC BY 4.0).

http://creativecommons.org/licenses/by/4.0/

\section{(c) (i) Open Access}

\begin{abstract}
The paper is based on the experimental investigation of accelerated stresses on insulation of power transformer. The effects of individual thermal and electrical stresses have been graphically presented. The factors accelerated thermal aging factor (ATAF) and accelerated electrical aging factor (AEAF) have been introduced, it helps to understand the contribution of thermal and electrical stresses and degradation trends of insulating properties. The accelerated aging factors have been mathematically correlated with different properties of insulation such as moisture, breakdown voltage (BDV), tan delta and resistivity. These parameters were determined experimentally for fresh oil samples and for samples subjected to accelerated aging.
\end{abstract}

\section{Keywords}

Accelerated Thermal Aging Factor (ATAF), Accelerated Electrical Aging Factor (AEAF), Moisture, Breakdown Voltage (BDV), Resistivity, Tan Delta

\section{Introduction}

The insulation of power transformer degraded under a combination of various stresses. The stresses reduce the dielectric capability of a transformer and increase the probability of failure. In this paper, the impact of accelerated stresses of power transformer insulation is presented. The various parameters used to measure these impacts are moisture, breakdown voltage (BDV), $\tan \delta$ and resistivity [1].

\section{Experimentation}

To measure the impact of accelerated thermal and electrical stresses on the transformer insulating oil, the special test cell shown in Figure 1 has been fabricated. The capacity of the test cell was 3 liters. The description of test cell is given in Table 1 [2]. 


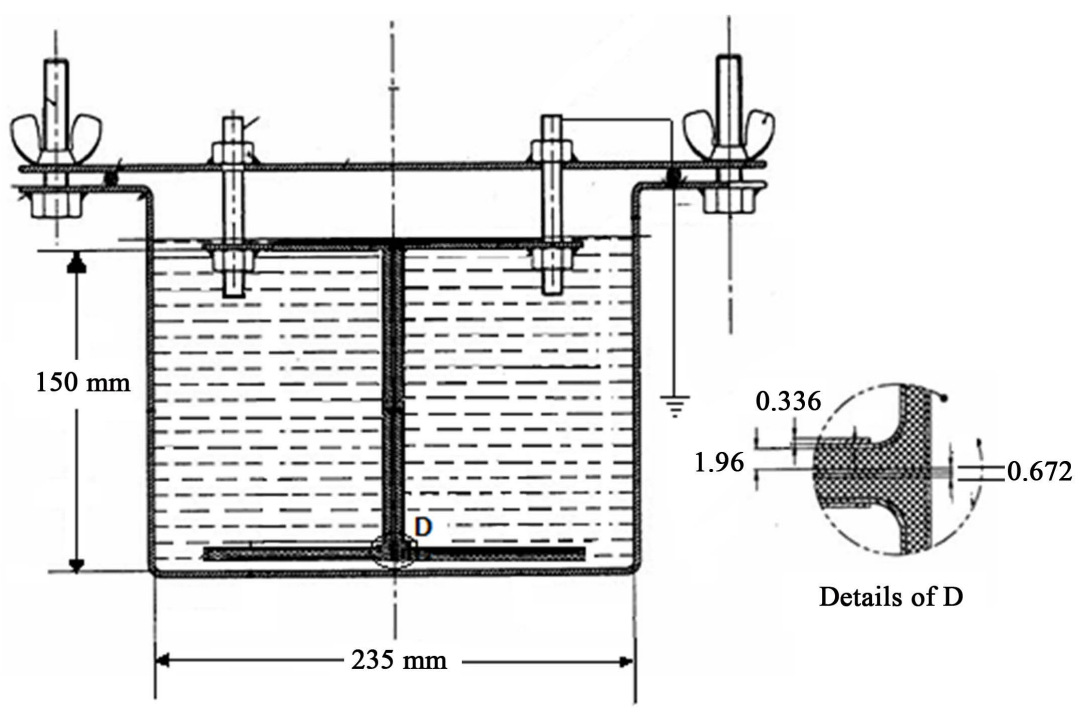

Figure 1. Test cell set up.

Table 1. Description of test cell.

\begin{tabular}{ccc}
\hline Description & Material & Dimension \\
\hline Cover plate & Mica sheet & $5 \mathrm{~mm}$ \\
Sealing ring & Silicone rubber & $5 \mathrm{~mm}$ \\
Tank & Mild steel (Coated with enamel paint) & $235 \mathrm{~mm} \times 100 \mathrm{~mm} \times 150 \mathrm{~mm}$ \\
Round stud and nut & Copper & 3 liter/cell \\
Bolt & Mild steel & $205 \mathrm{~mm} \times 12.5 \mathrm{~mm} \times 1.96 \mathrm{~mm}$ \\
Transformer oil & As per IS: 335 - 1993 (2005) & \\
Copper strip & Copper & \\
without paper wrapped & Electrical grade paper, & \\
Insulating paper & as per IS 9335-1993 & \\
& &
\end{tabular}

\section{Accelerated Aging Factors}

The aging of transformer insulation is intimately connected with the magnitude and duration of stresses. To understand the effect of thermal and electrical stresses on transformer insulation, accelerated thermal aging factor (ATAF) and accelerated electrical aging factor (AEAF) have been introduced:

$$
\begin{aligned}
& \text { ATAF }=T \times D, \text { unit is degree C-hours }\left({ }^{\circ} \mathrm{C}-\mathrm{hr}\right) \\
& \mathrm{AEAF}=E \times D, \text { unit is } \mathrm{kV} / \mathrm{mm} \text {-hours }(\mathrm{kV} / \mathrm{mm} \cdot \mathrm{hr})
\end{aligned}
$$

where $T$ is temperature in ${ }^{\circ} \mathrm{C}, D$ is the duration of stresses in hours and $E$ is electrical stresses in $\mathrm{kV} / \mathrm{mm}$.

Both factors help in generating the mathematical equation which helps in differentiate the degradation trends. The thermal stresses of $190^{\circ} \mathrm{C}, 200^{\circ} \mathrm{C}$ and $210^{\circ} \mathrm{C}$ and electrical stresses of $2 \mathrm{kV} / \mathrm{mm}, 4 \mathrm{kV} / \mathrm{mm}$ and $6 \mathrm{kV} / \mathrm{mm}$ were used. The electrical stresses have been performed at room temperature. The ATAF and AEAF were calculated using Equations (1) and (2) and results are shown in Table 2 and Table 3 [2]. 
Table 2. Accelerated Thermal Aging Factor (ATAF).

\begin{tabular}{|c|c|c|}
\hline Temperature $\left({ }^{\circ} \mathrm{C}\right)$ & Aging (hours) & $\operatorname{ATAF}\left({ }^{\circ} \mathrm{C}-\mathrm{hr}\right)$ \\
\hline 190 & 150 & $\mathrm{ATAF} 1=28,500$ \\
\hline 200 & 150 & $\mathrm{ATAF} 2=30,000$ \\
\hline 210 & 150 & ATAF3 $=31,500$ \\
\hline 190 & 300 & ATAF4 $=57,000$ \\
\hline 200 & 300 & ATAF5 $=60,000$ \\
\hline 210 & 300 & ATAF6 $=63,000$ \\
\hline 190 & 450 & ATAF7 $=85,500$ \\
\hline 200 & 450 & ATAF $8=90,000$ \\
\hline 210 & 450 & ATAF9 $=94,500$ \\
\hline 190 & 600 & ATAF10 $=114,000$ \\
\hline 200 & 600 & ATAF11 $=120,000$ \\
\hline 210 & 600 & $\mathrm{ATAF} 12=126,000$ \\
\hline 190 & 750 & ATAF13 $=142,500$ \\
\hline 200 & 750 & ATAF14 $=150,000$ \\
\hline 210 & 750 & ATAF $15=157,500$ \\
\hline
\end{tabular}

Table 3. Accelerated Electrical Aging Factor (AEAF).

\begin{tabular}{ccc}
\hline Electrical stress $(\mathrm{kV} / \mathrm{mm})$ & Aging (hours) & AEAF $(\mathrm{kV} / \mathrm{mm}-\mathrm{hr})$ \\
\hline 2 & 150 & AEAF1 $=300$ \\
2 & 150 & AEAF2 $=600$ \\
2 & 450 & \\
6 & 150 & AEAF3 $=900$ \\
2 & 600 & \\
4 & 300 & AEAF4 $=1200$ \\
2 & 750 & AEAF5 $=1500$ \\
4 & 450 & AEAF6 $=1800$ \\
6 & 300 & \\
4 & 600 & AEAF7 $=2400$ \\
6 & 450 & AEAF8 $=2700$ \\
4 & 750 & AEAF9 $=3000$ \\
6 & 600 & AEAF10 $=3600$ \\
6 & 750 & AEAF1 $=4500$ \\
\hline & &
\end{tabular}

\section{Moisture Content}

The virgin insulating oil and paper have moisture content of $50 \mathrm{ppm}$ and about $0.5 \%$ by weight respectively. Moisture in the transformer reduces the insulation strength. The main reasons for moisture content changes over the life cycle are: 
moisture interactivity with environment due to leakage, additional moisture generation due to chemical reactions [3], transformer breathing, decomposing the cellulosic materials under stresses, aging phenomena, exposure to atmospheric moisture during maintenance, failure to dry out the insulation during manufacturing [4]. The moisture content is a life-shortening parameter. It can weakens the withstand breakdown voltage of the insulation system [5], promotes local heating, reduces the overload capability of transformers in emergency conditions [6], accelerates the process of insulation deterioration [5], decreasing the electrical and mechanical strength [7]. Electrical or partial discharges can occur in a high voltage region due to a disturbance of the moisture equilibrium [8] [9] increase the electrical conductivity and dissipation factor. According to Fabre [10], the rate of thermal aging of paper is proportional to its moisture content. Moisture in transformer oil can also lead to partial discharge, bubble formation when high temperatures are attained in the winding and an abrupt desorption of moisture takes place from the paper toward the oil [9]. Moisture is a polar liquid having high permittivity and therefore is attracted to areas of strong electrical field [11]. As the transformer warms up, moisture migrates from the solid insulation into the fluid. The rate of migration depends on the conductor temperature and the rate-of-change of conductor temperature. The moisture moving between the cellulose and oil are different for each direction as the moisture in the cellulose is not evenly distributed. The migration of small amounts of moisture from paper to oil has been associated with the phenomenon of static electrification appearing when there is a charge accumulation on the interfaces between dry and humid zones [12] [13]. Moisture transfer can be activated by moisture concentration gradient, temperature gradient and pressure gradient [13]. In addition dissolved moisture in oil can precipitate out during rapid cool down periods and become free water which may or may not re-dissolve [14]. Excessive amounts of moisture can accelerate the degradation process of the cellulose and prematurely aged the transformers insulation system [14].

The moisture in cellulosic insulation may be determined from moisture in oil samples using oil/paper moisture equilibrium curves such as Fabre-Pichon curves, Oommen curves, Griffin curves, MIT curves [11] [16] Infra red techniques (IR) and Interfacial polarization (IP) [17] [18] [19].

\section{Breakdown Voltage (BDV)}

The breakdown voltage (BDV) is an important parameter to gauge the condition of oil. The BDV of oil is high when it is dry and clean, it goes down slowly as the moisture contents and conducting impurities increase as a result of oxidation of oil [20]. The BDV decreases consistently with aging because of release of moisture in the oil, due to increase in the size and number density of free particles generated due to dissolved gases and polar compounds, etc. [21]. The BDV bears a non-linear relationship with aging [20]. The breakdown characteristics depend on initial moisture of the insulation, initial temperature and temperature gradient. 


\section{Results and Discussions}

\section{A. MOISTURE CONTENTS}

The moisture of oil sample has been measured by automatic coulometric karl fischer titration equipment. As per IS 335:2005 and IS 13567:1992, moisture content in virgin oil should not be more than $50 \mathrm{ppm}$. Figure 2 indicates the variation of moisture content with aging at $190^{\circ} \mathrm{C}, 200^{\circ} \mathrm{C}$ and $210^{\circ} \mathrm{C}$. The insulation was aged at $0,150,300,450,600$ and 750 hours. The moisture content of virgin oil sample was $32.8 \mathrm{ppm}$. It increased to maximum value of $67.6 \mathrm{ppm}$ at $210^{\circ} \mathrm{C}$ after 750 hours of aging. Figure 3 indicates the graphical representation of moisture with ATAF. The most affective prediction model is with $\mathrm{R}^{2}=93.3 \%$. The mathematical correlation between moisture and ATAF is shown in Equation (1):

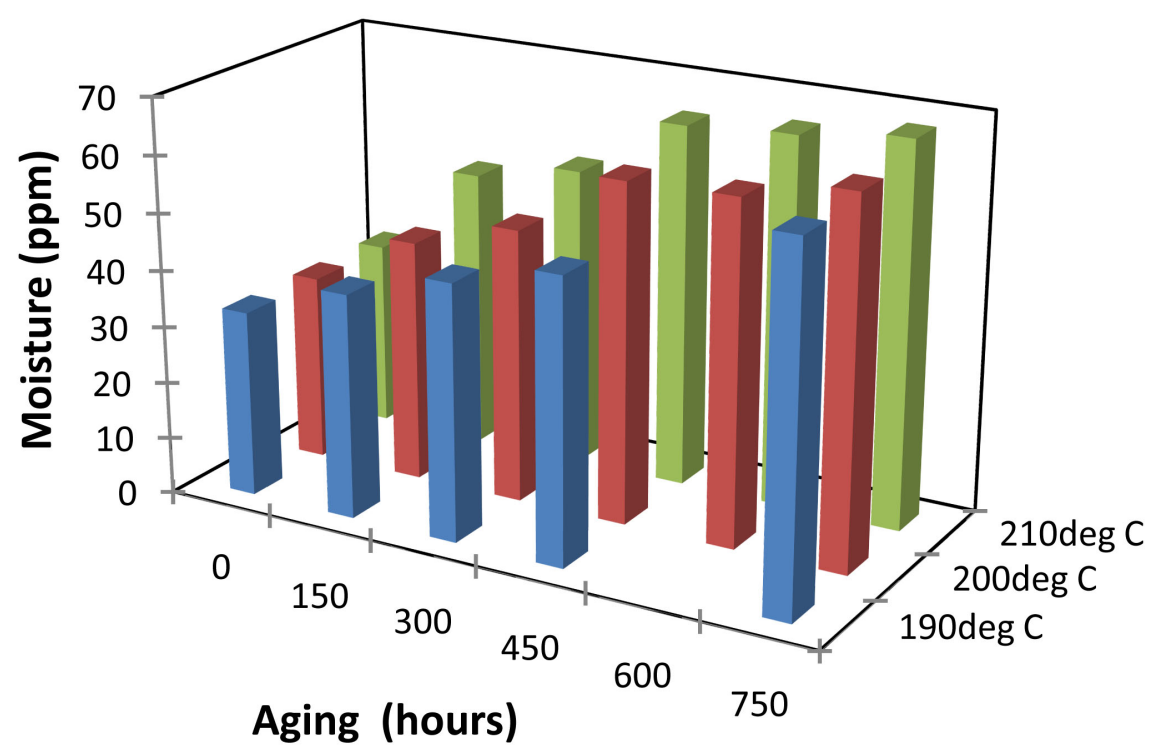

Figure 2. Variation of moisture with aging at $190^{\circ} \mathrm{C}, 200^{\circ} \mathrm{C}$ and $210^{\circ} \mathrm{C}$.

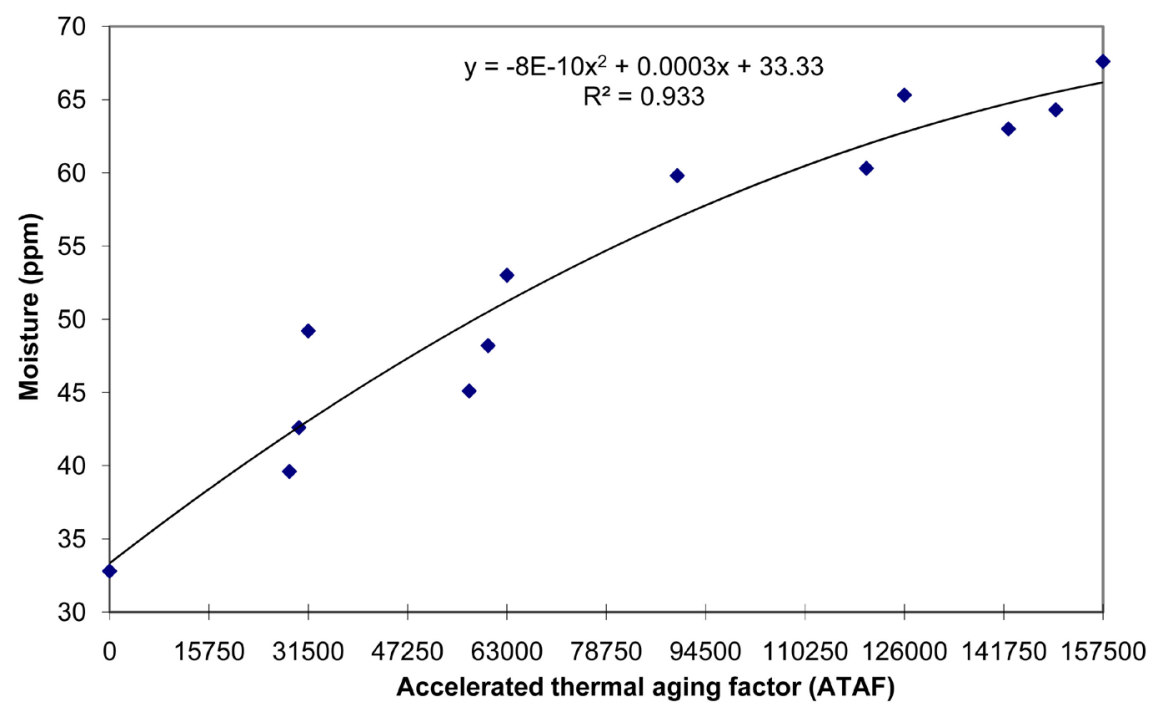

Figure 3. Correlation between moisture and ATAF. 


$$
\text { Moisture }=\left(-8 \times 10^{-10}\right) \mathrm{ATAF}^{2}+0.0003 \mathrm{ATAF}+33.33
$$

In Figure 4, the variation of moisture with aging and electrical stresses of 2 $\mathrm{kV} / \mathrm{mm}, 4 \mathrm{kV} / \mathrm{mm}$ and $6 \mathrm{kV} / \mathrm{mm}$ have been presented. The insulation was aged at $0,150,300,450,600$ and 750 hours. The maximum increase of moisture content is $61.7 \mathrm{ppm}$ at $6 \mathrm{kV} / \mathrm{mm}$ after 750 hours of aging. It indicates that the moisture content increases during thermal and electrical stress with aging.

Figure 5 shows the correlation between moisture and AEAF. The most effective prediction model is found with $\mathrm{R}^{2}=94.5 \%$. The mathematical correlation generated between moisture and AEAF is shown in Equation (2):

$$
\text { Moisture }=-2 \times 10^{-6} \mathrm{AEAF}^{2}+0.013 \mathrm{AEAF}+35.10
$$

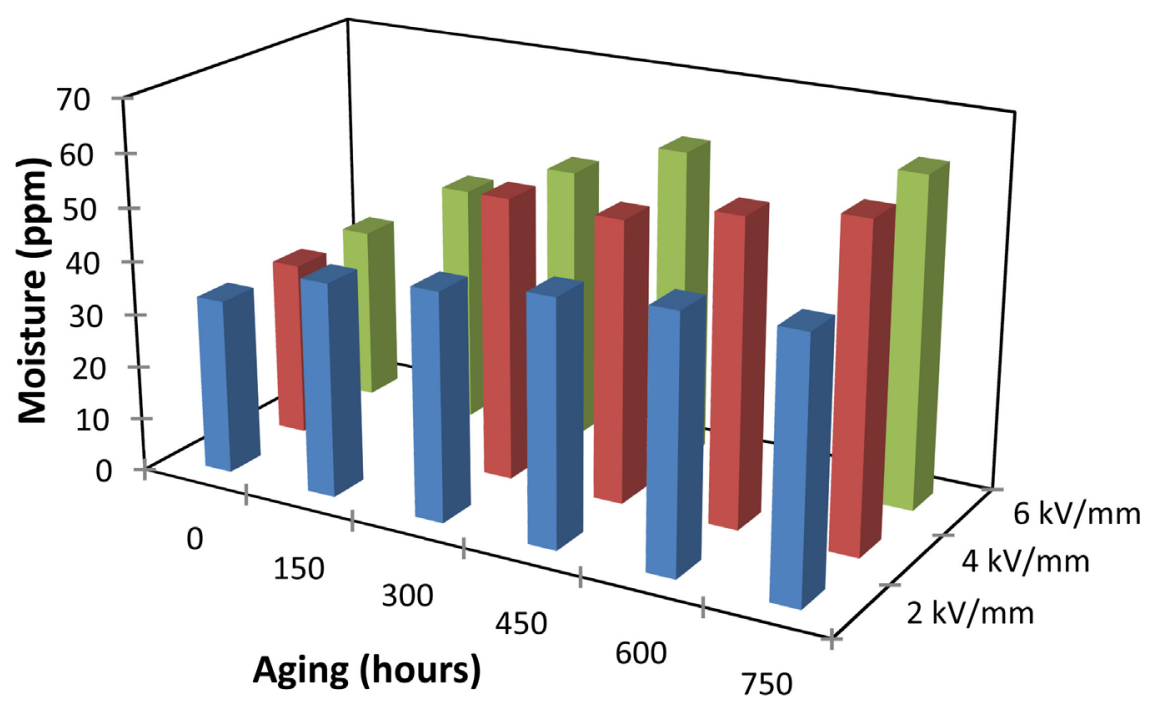

Figure 4. Variation of moisture with aging at $2 \mathrm{kV} / \mathrm{mm}, 4 \mathrm{kV} / \mathrm{mm}$ and $6 \mathrm{kV} / \mathrm{mm}$.

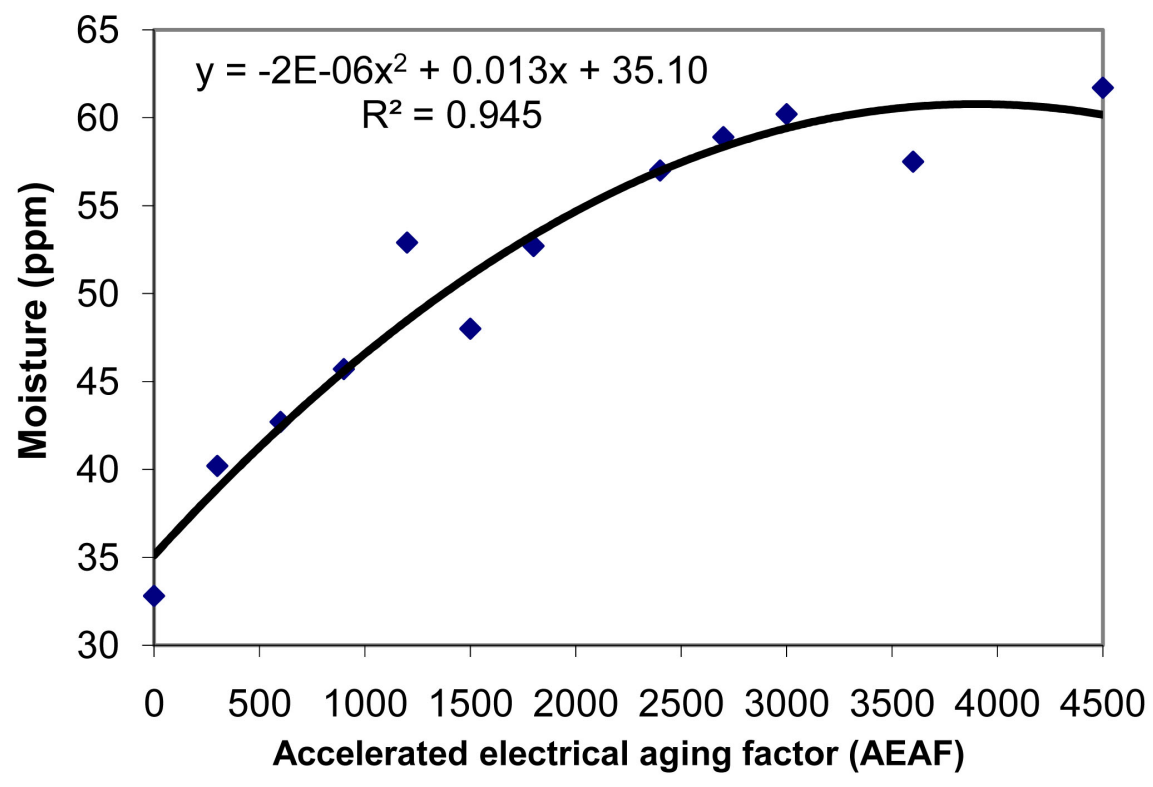

Figure 5. Correlation between moisture and AEAF. 
According to Fofana [22], due to aging process, the decomposition of hydrocarbon molecules takes place by thermal and electric stresses. The energy required for the decomposition of weakly bonded hydrocarbons is supplied by the high voltage stress. The absorption of large amount of energy causes excitation of molecules, which in certain cases leads to the hemolytic breakdown of weak chemical bonds generating "gases" (along with low molecular weight hydrocarbons)". When this process takes place, the evolved gases leave the broken molecules in the liquid phase, which act as free radical, and there is high probability that it will react with other similar free radical which is no longer soluble in the blend of hydrocarbons. Due to the decomposition of long hydrocarbon chains that leave molecules with a broken covalent bond in the oil, it increases the conductivity which further affects the moisture and breakdown.

\section{B. BREAKDOWN VOLTAGE (BDV)}

The BDV of oil sample have been measured by oil breakdown test set [23]. As per IS 335:2005 and 6792:1972, BDV of new oil should be $30 \mathrm{kV}$ (rms) minimum.

Figure 6 indicates the variation of BDV with aging for $190^{\circ} \mathrm{C}, 200^{\circ} \mathrm{C}$ and $210^{\circ} \mathrm{C}$. The $\mathrm{BDV}$ of virgin oil sample was $45.2 \mathrm{kV}$. After 750 hours of aging, the $\mathrm{BDV}$ decreases to $13.1 \mathrm{kV}$ at $210^{\circ} \mathrm{C}$. The scattered results in Figure 7 indicate that the BDV decreases with increase in ATAF. The most effective prediction model is found with $\mathrm{R}^{2}=92.9 \%$. The Equation (3) represents the mathematical correlation between BDV and ATAF.

$$
\mathrm{BDV}=\left(1 \times 10^{-09}\right) \mathrm{ATAF}^{2}-0.0004 \mathrm{ATAF}+44.13
$$

Figure 8 indicates that the variation of the BDV with aging for 2, 4 and 6 $\mathrm{kV} / \mathrm{mm}$. After 750 hours of electrical stress, the maximum decrease of BDV is $29.4 \mathrm{kV}$ at $6 \mathrm{kV} / \mathrm{mm}$. Figure 9 exhibits a decreasing pattern of AEAF wih BDV [24]. The most effective prediction model is found with $R^{2}=91.9 \%$. The Equa-

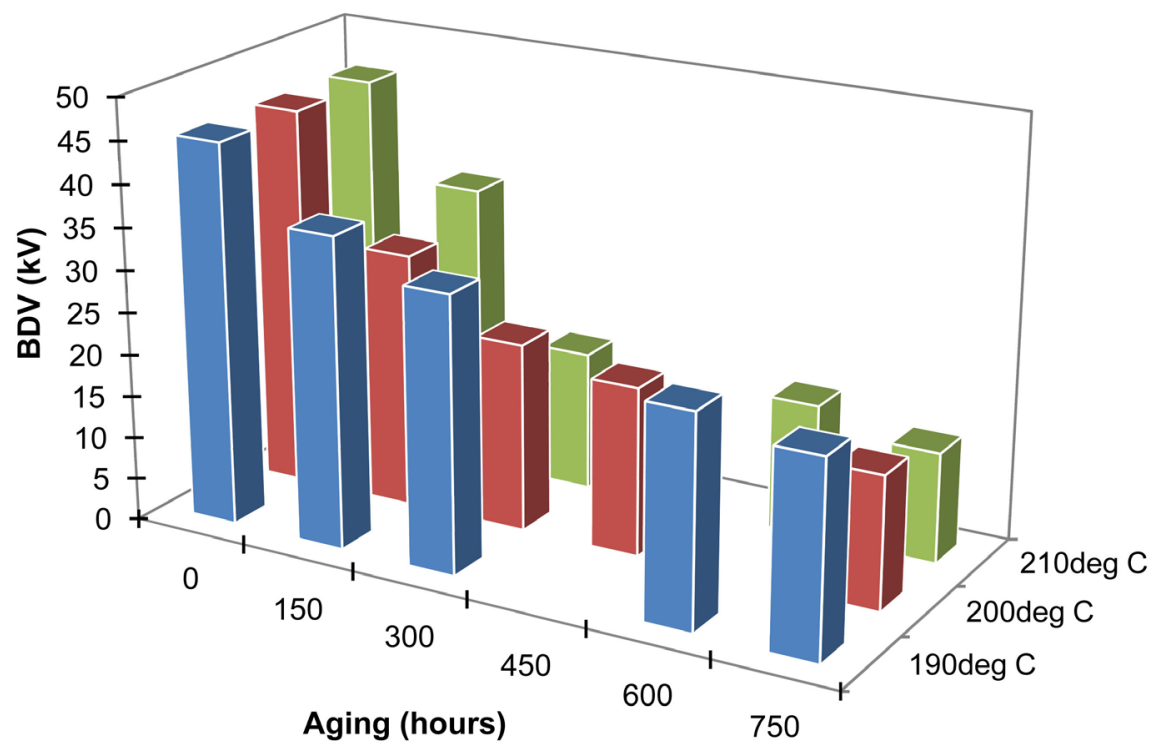

Figure 6. Variation of BDV with aging at $190^{\circ} \mathrm{C}, 200^{\circ} \mathrm{C}$ and $210^{\circ} \mathrm{C}$. 


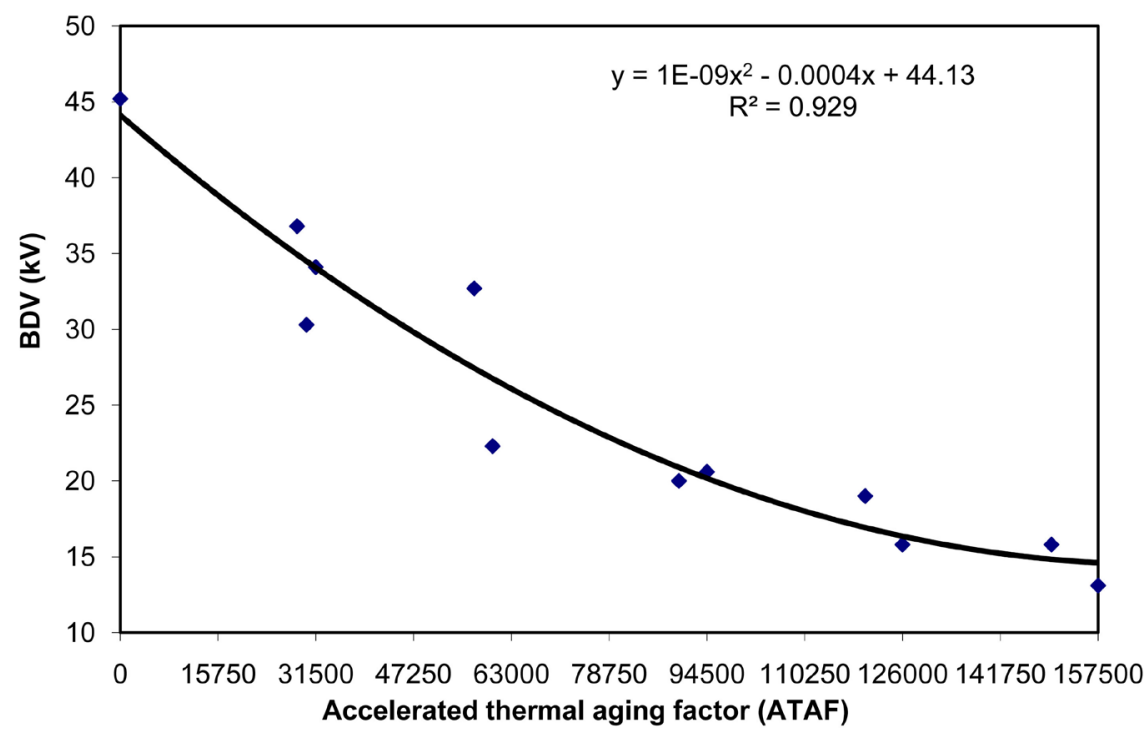

Figure 7. Correlation between BDV and ATAF.

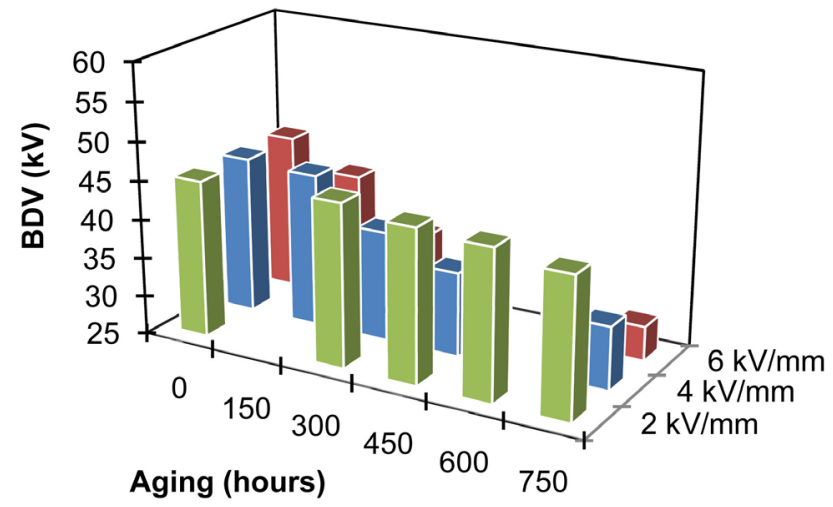

Figure 8. Variation of BDV with aging at $2 \mathrm{kV} / \mathrm{mm}, 4 \mathrm{kV} / \mathrm{mm}$ and $6 \mathrm{kV} / \mathrm{mm}$.

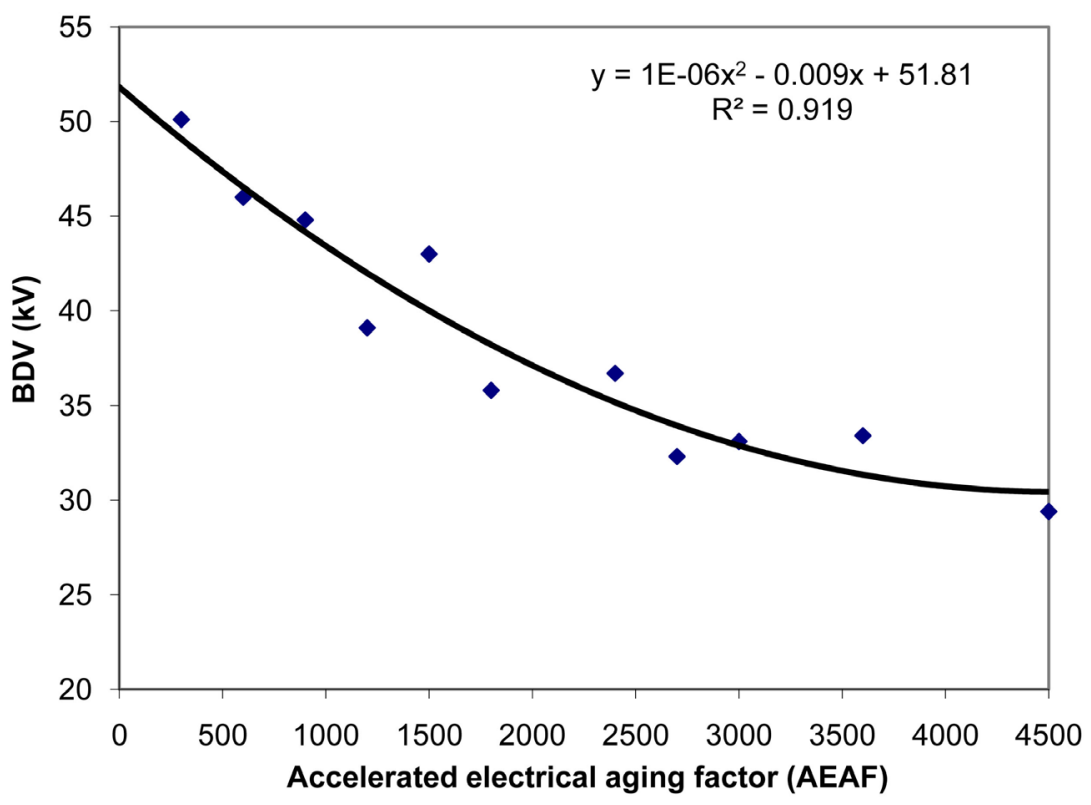

Figure 9. Correlation between BDV and AEAF. 
tion (4) represents the mathematical correlation between BDV and AEAF.

$$
\mathrm{BDV}=\left(1 \times 10^{-06}\right) \mathrm{AEAF}^{2}-0.009 \mathrm{AEAF}+51.81
$$

\section{Dielectric Dissipation Factor or Tan Delta}

The $\tan \delta$ is very important parameter to measure the quality of the insulation. The variation of $\tan \delta$ with applied voltage provides useful information about the source of any imperfection in the insulation. It increases with insulation deterioration and serves as an early indicator of failure hazards. A low value of tan $\delta$ is generally desirable. The high value of $\tan \delta$ gives an early indication of the contamination and presence of moisture content, conductive contamination, soluble varnishes, resins etc. [25].

\section{Resistivity}

Resistivity is the most sensitive property of oil, it varies with temperature. It is desirable to have resistivity of oil as high as possible. It reduces considerably due to presence of moisture, acidity and solid contaminants [17] [26]. High resistivity reflects low content of free ions and ion-forming particles, and indicates a low concentration of conductive contaminants [27]. Contamination of oil, which would not otherwise be detected by acidity test, will immediately be detected by the changes in the value of resistivity.

\section{Results and Discussions}

\section{A. Resistivity}

The resistivity of oil sample has been measured by Automatic dielectric constant, tan delta and resistivity (ADTR-2K) equipment. As per IS 335:2005 and IS $6103: 1971$, the resistivity of fresh oil is $35 \mathrm{TOhm}-\mathrm{cm}\left(35 \times 10^{12} \mathrm{Ohm}-\mathrm{cm}\right)$ at $90^{\circ} \mathrm{C}$, minimum.

Figure 10 indicates the variation of resistivity with aging for $190^{\circ} \mathrm{C}, 200^{\circ} \mathrm{C}$ and $210^{\circ} \mathrm{C}$ respectively. The resistivity of fresh oil sample at $90^{\circ} \mathrm{C}$ was very high,

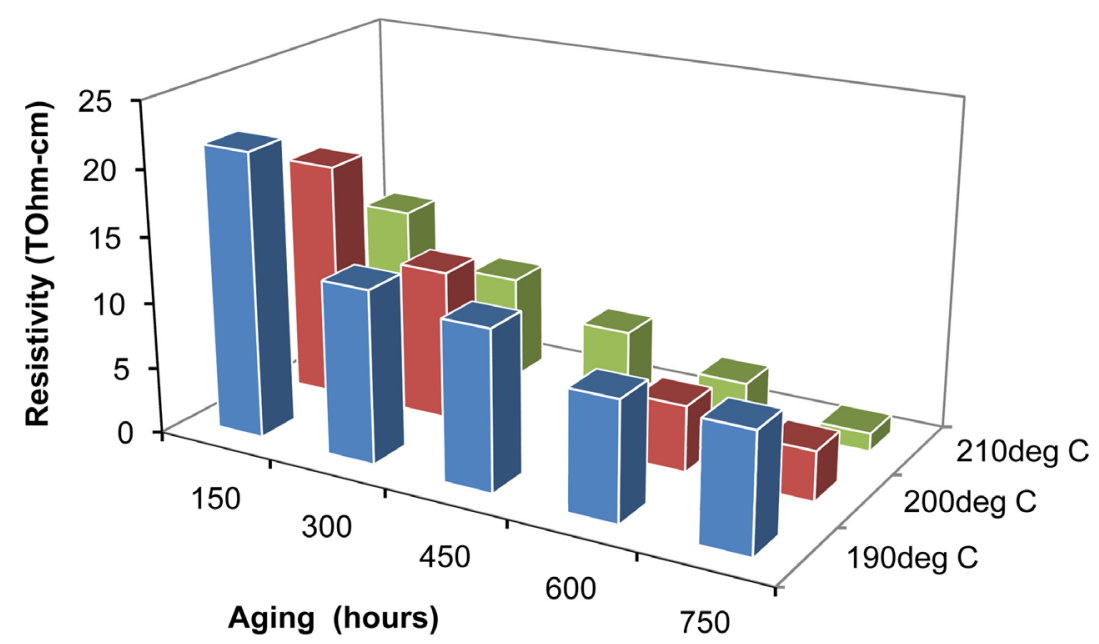

Figure 10 . Variation of resistivity with aging at $190^{\circ} \mathrm{C}, 200^{\circ} \mathrm{C}$ and $210^{\circ} \mathrm{C}$. 
so it should be neglected in the graphical representation. After 750 hours of aging, maximum decrease of resistivity was $1.374 \mathrm{TOhm}-\mathrm{cm}$ at $210^{\circ} \mathrm{C}$. The results of Figure 11 indicate that resistivity decreases with ATAF. The most effective prediction model is found with $\mathrm{R}^{2}=94.4 \%$. The mathematical correlation generated between resistivity and ATAF is given in Equation (5):

$$
\text { Resisivity }=\left(1 \times 10^{-09}\right) \mathrm{ATAF}^{2}-0.0004 \mathrm{ATAF}+29.67
$$

Figure 12 indicates the variation of resistivity with aging for 2, 4 and 6 $\mathrm{kV} / \mathrm{mm}$. After 750 hours of aging under electrical stresses, maximum decrease in resistivity was $2.087 \mathrm{TOhm}-\mathrm{cm}$ at $6 \mathrm{kV} / \mathrm{mm}$. The non-linear relation of resistivity with AEAF is shown in Figure 13. The most effective prediction model is

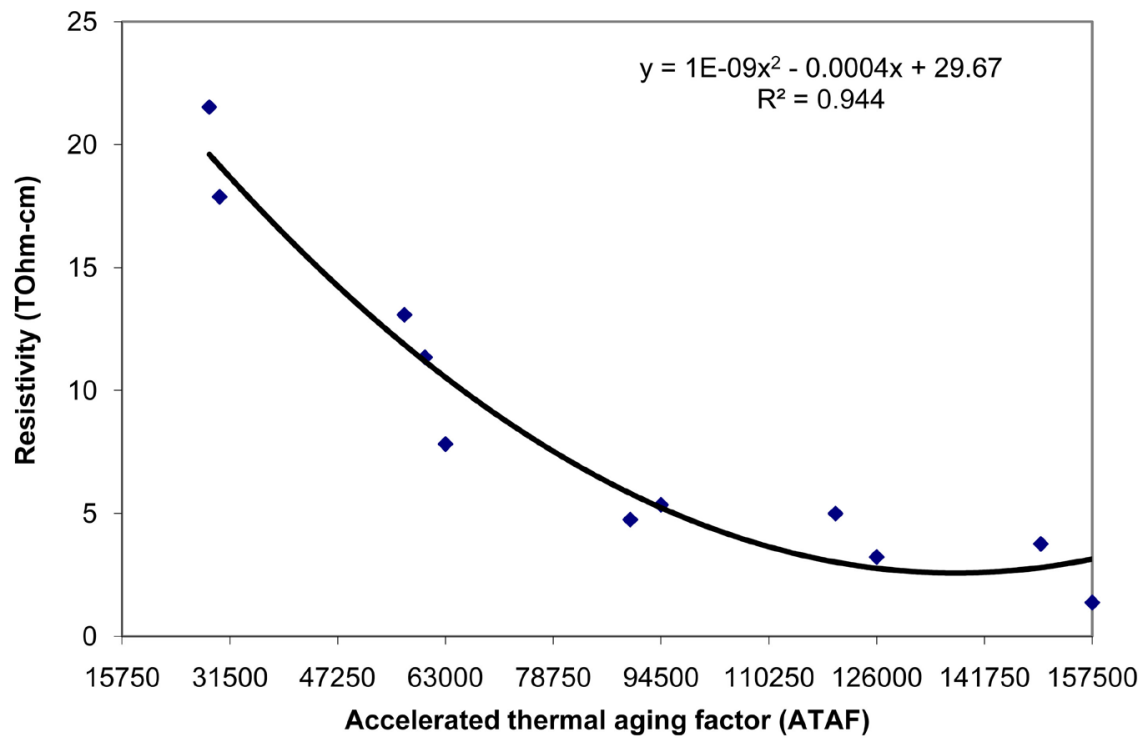

Figure 11. Correlation between resistivity with ATAF.

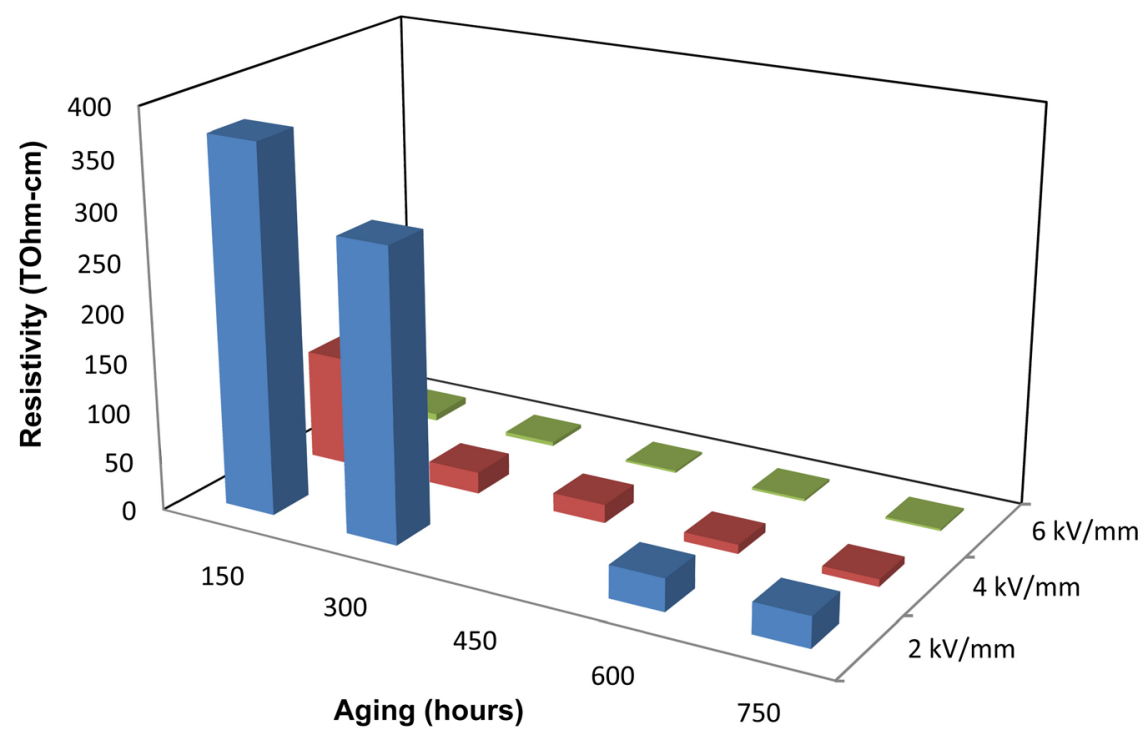

Figure 12 . Variation of resistivity with aging at $2 \mathrm{kV} / \mathrm{mm}, 4 \mathrm{kV} / \mathrm{mm}$ and $6 \mathrm{kV} / \mathrm{mm}$. 


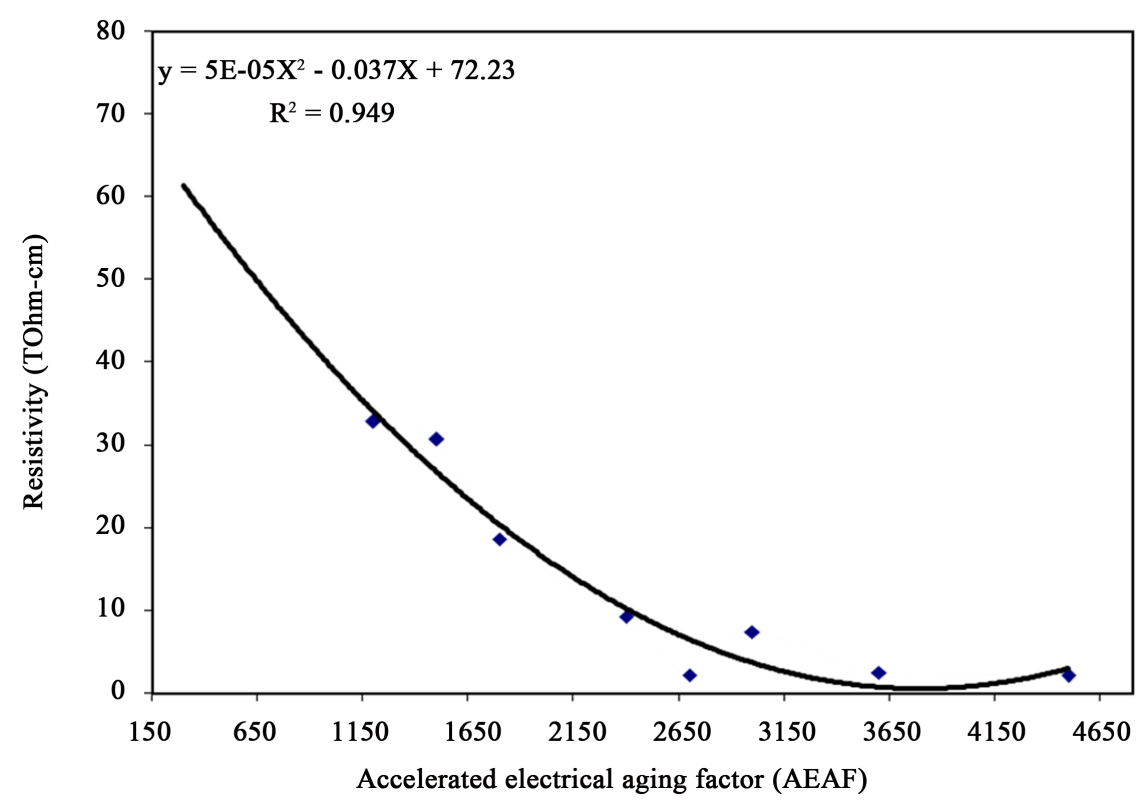

Figure 13. Correlation between resistivity and AEAF.

found with $R^{2}=94.9 \%$. The mathematical correlation generated between resistivity and AEAF is given in Equation (6):

$$
\text { Resisivity }=\left(5 \times 10^{-06}\right) \mathrm{AEAF}^{2}-0.037 \mathrm{AEAF}+72.23
$$

\section{B. Dielectric Dissipation Factor (DDF) or Tan Delta}

Figure 14 shows the variation of $\tan \delta$ with aging for thermal stresses at $190^{\circ} \mathrm{C}, 200^{\circ} \mathrm{C}$ and $210^{\circ} \mathrm{C}$. The $\tan \delta$ of oil sample has been measured by Automatic dielectric constant, tan delta and resistivity (ADTR-2K) equipment. As per IS 6262:1971 and IS 335:2005, good oil should have $\tan \delta$ of 0.002 (maximum) at $90^{\circ} \mathrm{C}$. In our finding, $\tan \delta$ of fresh oil sample at $90^{\circ} \mathrm{C}$ was 0.00216 . After 750 hours of aging, the maximum increase of $\tan \delta$ was 0.1067 at $210^{\circ} \mathrm{C}$.

The scattered results of Figure 15 indicate that $\tan \delta$ increases with ATAF. There is generally a relationship between $\tan \delta$ and resistivity, both being affected by same contaminants. A decrease in resistivity is coupled with an increase in $\tan \delta$. The most effective prediction model is found with $\mathrm{R}^{2}=95.1 \%$. The mathematical correlation generated between $\tan \delta$ and ATAF is shown in Equation (7):

$$
\tan \delta=\left(8 \times 10^{-12}\right) \mathrm{ATAF}^{2}-\left(6 \times 10^{-07}\right) \mathrm{ATAF}+0.013
$$

Figure 16 indicates the variation of $\tan \delta$ with aging for 2,4 and $6 \mathrm{kV} / \mathrm{mm}$. After 750 hours of electrical stress, maximum increase of $\tan \delta$ was 0.031 at 6 $\mathrm{kV} / \mathrm{mm}$. It indicates that $\tan \delta$ is affected by aging, thermal stresses and electrical stresses. In Figure 17, resistivity increases polynomial with accelerated electrical stresses. The most effective prediction model is found with $\mathrm{R}^{2}=94.3 \%$. The mathematical correlation generated between $\tan \delta$ and AEAF is shown in Equation 8:

$$
\tan \delta=\left(1 \times 10^{-09}\right) \mathrm{AEAF}^{2}+\left(1 \times 10^{-06}\right) \mathrm{AEAF}+0.001
$$




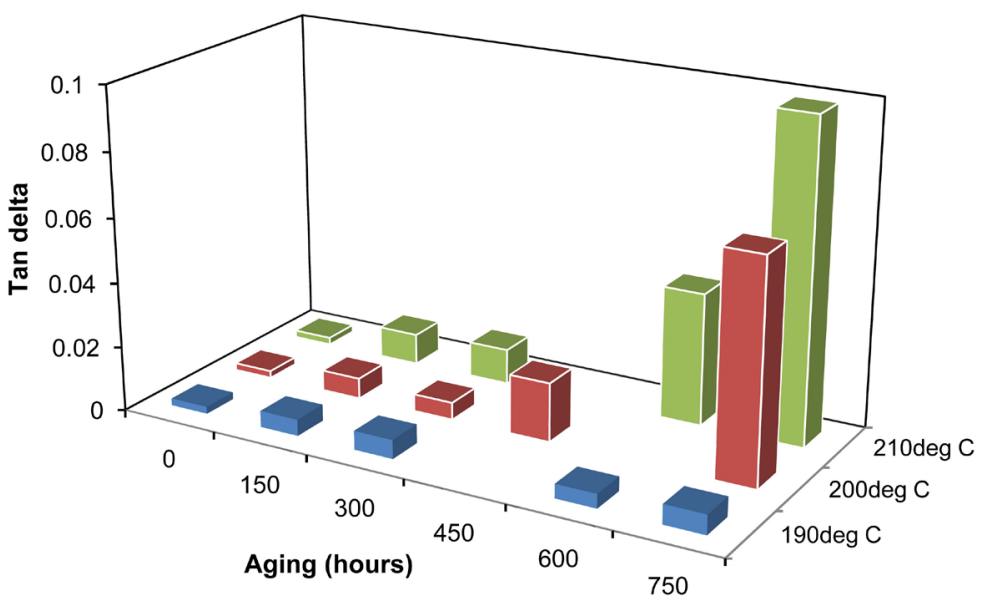

Figure 14 . Variation of $\tan \delta$ with aging at $190^{\circ} \mathrm{C}, 200^{\circ} \mathrm{C}$ and $210^{\circ} \mathrm{C}$.

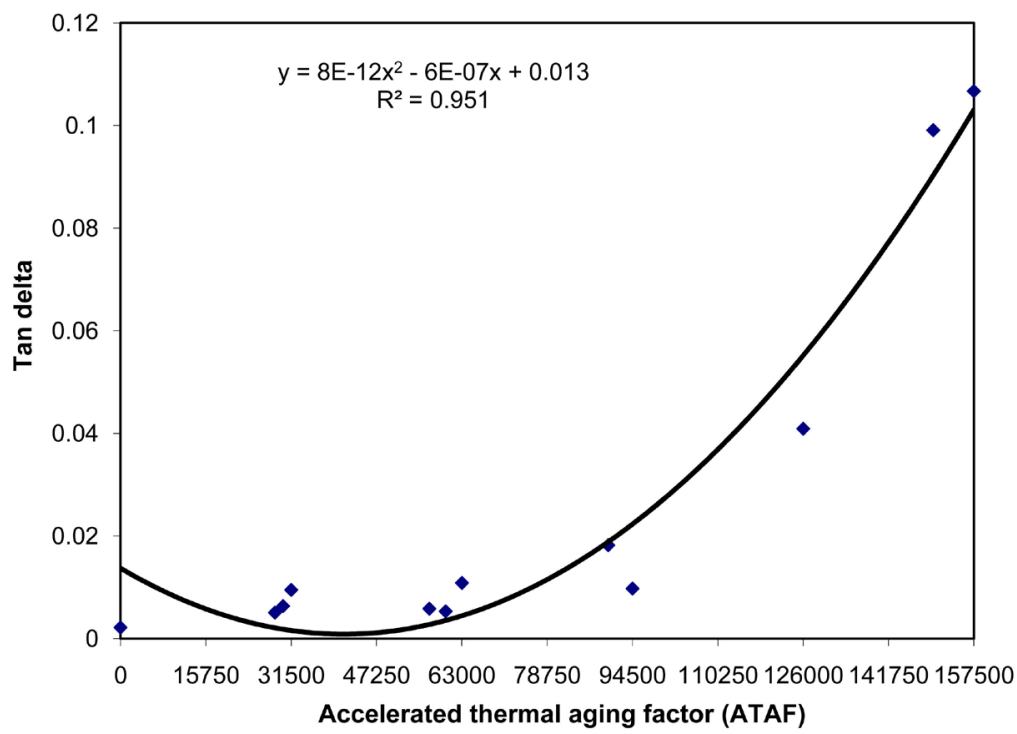

Figure 15. Correlation between $\tan \delta$ and ATAF.

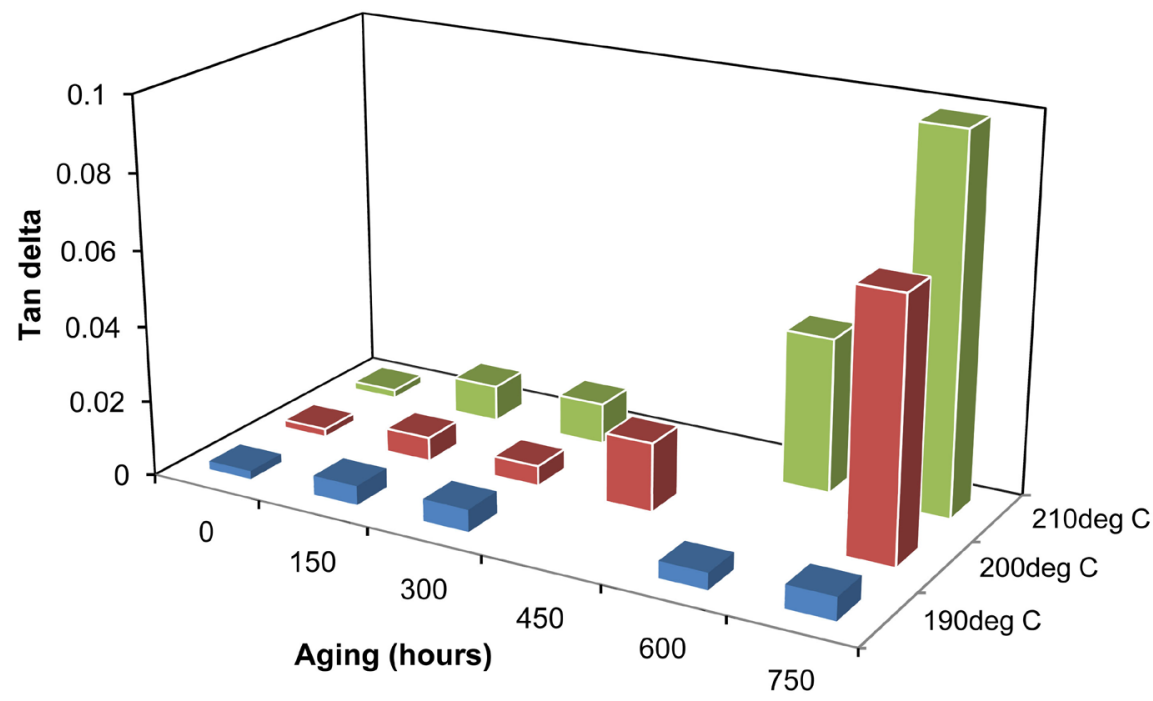

Figure 16. Variation of $\tan \delta$ with aging at 2, 4 and $6 \mathrm{kV} / \mathrm{mm}$. 


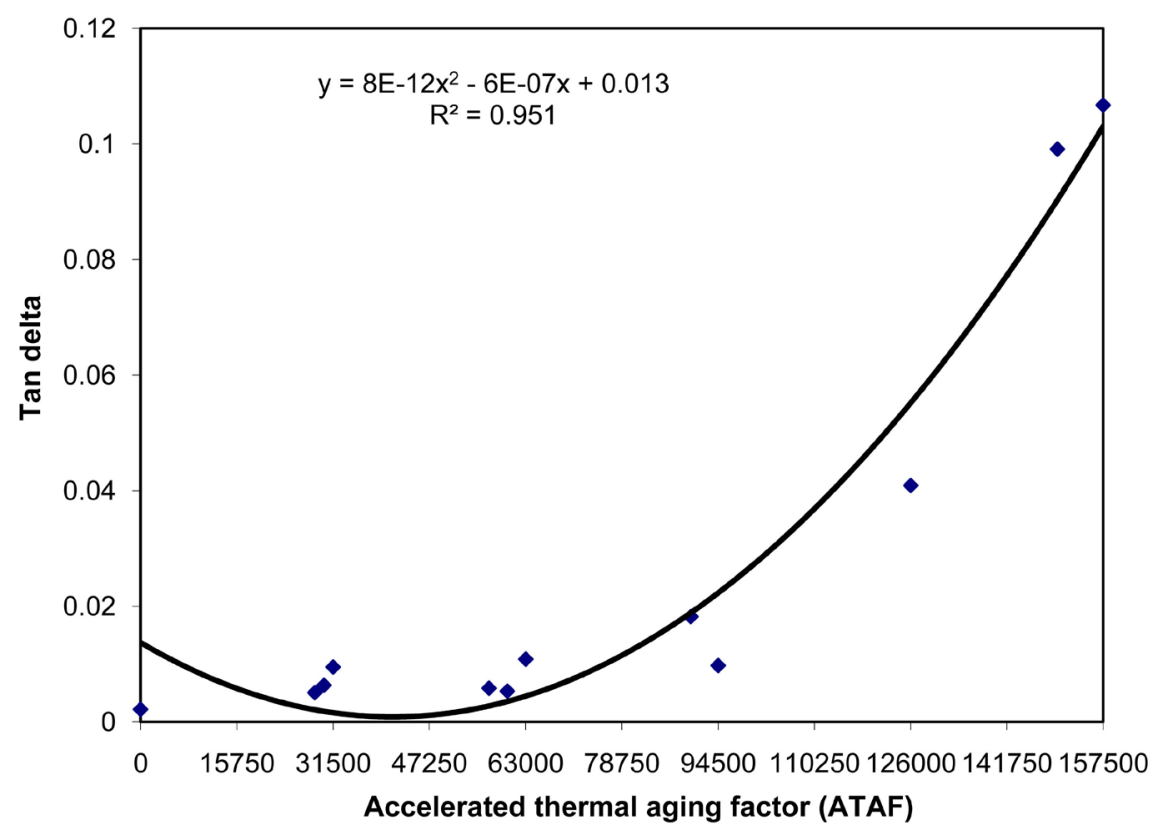

Figure 17. Correlation between $\tan \delta$ and AEAF.

\section{Conclusions}

The effect of thermal and electrical stresses on the transformer oil has been experimentally investigated in this paper. The term accelerated thermal aging factor (ATAF) and accelerated electrical aging factor (AEAF) have been introduced in order to quantify the thermal and electrical stresses. The graphically representation between moisture, BDV, tan delta and resistivity with aging, ATAF and AEAF has been presented. It is presented that as the moisture increases with ATAF and AEAF, the BDV decreases in same pattern. Similarly as tan delta increases with ATAF and AEAF, resistivity decreases with same pattern. It is due to the fact that these properties are affected by the same contaminants.

This paper contributes that electrical stresses also play an important role in the degradation of the insulation along with thermal stresses but the degradation of insulation by thermal stresses is comparatively more as compared to electrical stresses. Further, all the properties were correlated with ATAF and AEAF and mathematical correlation has been generated.

\section{Acknowledgements}

The authors are thankful to Punjab Technical University, Jalandhar \& Technology Information Forecasting and Assessment Council and Centers of Relevance and Excellence (TIFAC-CORE) on Power Transformer Diagnostics and Dr. R. K. Jarial, Associate Professor and Office-in-charge, HV Lab, NIT Hamirpur for providing necessary infrastructural facilities for carrying out the research work.

\section{References}

[1] Emsley, A.M. and Stevens, G.C. (1992) A Reassessment of the Low Temperature Thermal Degradation of Cellulose. International Conference on Dielectric Mate- 
rials, Measurements and Applications, Manchester, 7-10 September 1992, 229-232.

[2] Singh, J., Sood, Y.R. and Verma, P. (2011) Experimental Investigation Using Accelerated Aging Factors on Dielectric Properties of Transformer Insulating Oil. Electric Power Components and Systems, 39, 1045-1059.

[3] Buerschaper, B., Kleboth-Lugova, O. and Leibfried, T. (2003) The Electrical Strength of Transformer Oil in a Transformer Board-Oil System during Moisture Non-Equilibrium. The Conference on Electrical Insulation and Dielectric Phenomena, Albuquerque, 19-22 October 2003, 269-272.

[4] Singh, J., Sood, Y.R. and Verma, P. (2012) The Influence of Service Aging on Transformer Insulating Oil Parameters. IEEE Transactions on Dielectrics and Electrical Insulation, 19, 421-426.

[5] Akbari, A., Dehpahlevan, S. and Borsi, H. (2006) Analyzing Dynamic of Moisture Equilibrium in Oil-Paper Insulation in Power Transformers for Efficient Drying. The Conference on Electrical Insulation and Dielectric Phenomena, Kansas City, 15-18 October 2006, 545-548. https://doi.org/10.1109/ceidp.2006.311990

[6] Gupta, B.K. (1998) Direct Determination of Moisture in Solid Oil-Paper Insulation. IEEE International Symposium on Electrical Insulation, Arlington, 7-10 June 1998, 583-586. https://doi.org/10.1109/elinsl.1998.694860

[7] Clark, F.M. (1942) Factors Affecting the Mechanical Deterioration of Cellulose Insulation. Transaction on Electrical Engineering, 61, 742-749.

[8] Moser, H.P. (1979) Transformer Board, Special Print of Scientia Electrica.

[9] Garcia, B., Burgos, J.C., Alonso, A.M. and Sanz, J. (2005) A Moisture-in-Oil Model for Power Transformer Monitoring-Part I: Theoretical Foundation. IEEE Transactions on Power Delivery, 20, 1417-1422.

[10] Fabre, J. and Pichon, A. (1969) Deteriorating Processes and Products of Paper in Oil Application to Transformers. International Conference on Large High Voltage Electric Systems, Paris, Paper 137.

[11] Pahlavanpour, M. and Eklund, M. (2003) Study of Moisture Equilibrium in OilPaper System with Temperature Variation. International Conference on Properties and Applications of Dielectric Materials, Vol. 3, Nagoya, 1-5 June 2003, 1124-1129.

[12] Morin, A.J., Zahn, M. and Melcher, J.R. (1991) Fluid Electrification Measurements of Transformer Pressboard/Oil Insulation in a Couette Charge. IEEE Transactions on Electrical Insulation, 26, 870-901.

[13] Washabaugh, A.P., von Guggenberg, P.A., Zahn, M. and Melcher, J. (1991) Temperature and Moisture Transient Flow Electrification Measurements of Transformer Pressboard/Oil Insulation Using a Couette Facility. International Conference on Properties and Applications of Dielectric Materials, Vol. 2, Tokyo, 8-12 July 1991, 870-901.

[14] Ward, B.H. (2001) A Survey of New Techniques in Insulation Monitoring of Power Transformers. IEEE Electrical Insulation Magazine, 17, 16-23.

[15] Chu, D. and Lux, A. (1999) On-Line Monitoring of Power Transformers and Components: A Review of Key Parameters. Proceedings. Electrical Insulation Conference and Electrical Manufacturing and Coil Winding Conference, Cincinnati, 28 October 1999, 669-675. https://doi.org/10.1109/EEIC.1999.826290

[16] Du, Y., Zahn, M., Lesieutm, B.C., Mamishev, A.V. and Lindgren, S.R. (1999) Moisture Equilibrium in Transformer Paper-Oil Systems. IEEE Electrical Insulation Magazine, 15, 11-20.

[17] Darveniza, M., Saha, T.K., Hill, D.J.T. and Le, T.T. (1998) Investigations into Effective Methods for Assessing the Condition of Insulation in Aged Power Transfor- 
mers. IEEE Transactions on Power Delivery, 13, 1214-1223.

[18] Griffin, P.J. (1996) Water in Transformers-So What! National Grid Cond.

[19] Oommen, T.V. (1983) Moisture Equilibrium in Paper-Oil Insulation Systems. Electrical/Electronics Insulation Conference, Chicago, 3-6 October 1983, 162-166.

[20] Pradhan, M.K. and Ramu, T.S. (2004) Criteria for Estimation of End of Life of Power and Station Transformers in Service. Electrical Insulation and Dielectric Phenomena, Boulder, 17-20 October 2004, 220-223. https://doi.org/10.1109/ceidp.2004.1364228

[21] Arakelian, V.G. and Fofana, I. (2007) Water in Oil-Filled High-Voltage Equipment Part I: Water Content as Physicochemical Tools for Insulation Condition Diagnostic. IEEE Electrical Insulation Magazine, 23, 15-24.

[22] Fofana, I., N'cho, J.S., Aka-Ngnui, T. and Beroual, A. (2010) Effect of Electrical Discharge on Oil Decaying Process. International Conference on High Voltage Engineering and Application, New Orleans, 11-14 October 2010, 564-567.

[23] Myers, C. (1998) Transformer-Condition Monitoring by Oil Analysis Large or Small Contentment or Catastrophe. 1st IEE/IMechE International Conference on Power Station Maintenance-Profitability through Reliability, Edinburgh, 30 March1 April 1998, 53-58. https://doi.org/10.1049/cp:19980061

[24] Pradhan, M.K. (2006) Assessment of the Status of Insulation during Thermal Stress Accelerated Experiments on Transformer Prototypes. IEEE Transactions on Dielectrics and Electrical Insulation, 13, 227-237.

[25] American Standard, ASTM D 924:04, “Standard Test Method for Dissipation Factor (or Power Factor) and Relative Permittivity (Dielectric Constant) of Electrical Insulating Liquids".

[26] Verma, P., Roy, M., Verma, A., Bhanot, V. and Pandey, O.P. (2005) Changes in Electrical and Chemical Properties of Transformer Oil under Accelerated Thermal Stress and Its Service Life. Rhinology International Journal, 8, 42-48.

[27] Indian Standard, IS 6103:1971, "Method of Test for Specific Resistance (Resistivity) of Electrical Insulating Liquids".

\section{Submit or recommend next manuscript to SCIRP and we will provide best service for you:}

Accepting pre-submission inquiries through Email, Facebook, LinkedIn, Twitter, etc. A wide selection of journals (inclusive of 9 subjects, more than 200 journals) Providing 24-hour high-quality service User-friendly online submission system Fair and swift peer-review system Efficient typesetting and proofreading procedure Display of the result of downloads and visits, as well as the number of cited articles Maximum dissemination of your research work

Submit your manuscript at: http://papersubmission.scirp.org/ Or contact epe@scirp.org 